\title{
Predicitive modeling, empowering women, and COVID-19 in South Sumatra, Indonesia
}

\author{
Yeni Yeni \\ Department of Biostatistics, Faculty of Public Health, Sriwijaya University, Indonesia, \\ yenidoanks88@gmail.com \\ Najmah Najmah \\ Department of Epidemology, Faculty of Public Health, Sriwijaya University, Indonesia, \\ thn2949@autuni.ac.nz
}

See next page for additional authors

Follow this and additional works at: https://scholarhub.ui.ac.id/ajce

Part of the Social and Behavioral Sciences Commons

\section{Recommended Citation}

Yeni, Yeni; Najmah, Najmah; and Davies, Sharyn Graham (2020). Predicitive modeling, empowering women, and COVID-19 in South Sumatra, Indonesia. ASEAN Journal of Community Engagement, 4(1). Available at: https://doi.org/10.7454/ajce.v4i1.1094

Creative Commons License

(c) (i) ()

This work is licensed under a Creative Commons Attribution-Share Alike 4.0 License.

This Research Article is brought to you for free and open access by the Universitas Indonesia at ASEAN Journal of Community Engagement. It has been accepted for inclusion in ASEAN Journal of Community Engagement. 


\title{
Predictive modeling, empowering women, and COVID-19 in South
}

\author{
Sumatra, Indonesia \\ Yenia*, Najmah $^{b}$, Sharyn Graham Davies ${ }^{c}$ \\ aDepartment of Biostatistics, Faculty of Public Health, Sriwijaya University, Indonesia \\ ${ }^{b}$ Department of Epidemology, Faculty of Public Health, Sriwijaya University \\ ${ }^{c}$ Director of the Monash Herb Feith Indonesian Engagement Centre, Monash University, Australia
}

Received: June $23^{\text {rd }}, 2020$ || Revised: July $12^{\text {th }} \& 18^{\text {th }}, 2020$ || Accepted: July $2^{\text {th }}, 2020$

\begin{abstract}
The Coronavirus disease (COVID-19) has spread to almost all provinces in Indonesia, including South Sumatra. Epidemiological models are required to provide evidence for public health policymakers to mitigate the virus. The aim of this study is: 1) to create a prediction model for COVID-19 cases in South Sumatra to help inform about public health policy and 2) to reflect on women's experiences to provide solutions for mitigating the impact of COVID-19. This study uses quantitative and qualitative methods. A quantitative modeling approach called SusceptibleInfected-Recovered (SIR) model is used to predict COVID-19 cases in South Sumatra. The assumption used is that every four days, a doubling of COVID-19 cases is observed, with an average of 15 days for recovery. The sources of data are reports from the South Sumatra Provincial Government and the Ministry of Health of the Republic of Indonesia (MOH RI). Qualitative data are obtained through a feminist participatory action research project, which is focused on children's experiences of COVID-19. Reflective analysis is conducted to develop insights into how to empower women with respect to mitigating COVID-19. Results show that COVID-19 cases in South Sumatra are still underreported, with only 5\%-10\% of the total estimated COVID-19 cases being reported. Modeling indicates that over 1,000 people had COVID19 by the end of April, reaching over 150,000 by the end of May, and over a third of South Sumatra's population is likely to be infected by the end of June. Multiple interventions are needed to reduce cases and flatten the curve. Women are key to flattening this curve and must be empowered to undertake actions from a familial base.
\end{abstract}

Keywords: COVID-19; South Sumatra; multiple intervention; public health; prediction; women's empowerment.

\section{Introduction}

The Coronavirus disease (COVID-19) is a new type of coronavirus, originating in Wuhan, China, in late 2019 and spreading to most countries in the world by June 2020. COVID-19 was recognized as a global pandemic by the World Health Organization (WHO) on March 11, 2020 (Bedford et al., 2020; World Health Organization, 2020). By July 8, 2020, COVID-19 had spread to over 213 countries with over 12 million cases (Worldometer, 2020). Five countries experienced particularly high numbers of COVID-

\footnotetext{
*Correspondence Author: yenidoanks88@gmail.com
} 
Yeni, Najmah, Sharyn Davies | ASEAN Journal of Community Engagement | Volume 4, Number 1, 2020

19 cases early on, including the United States, Brazil, India, Russia, and Peru (Johns Hopkins University \& Medicine, 2020).

In Southeast Asia, Indonesia reported the first-highest number of COVID-19 cases after Singapore. Indonesia also had the highest mortality rate at approximately 5.9\%, indicating that out of 100 people, six would pass away due to COVID-19, as of July 8, 2020 (Table 1) (Worldometer, 2020). The number of active cases of COVID-19 in Indonesia is as high as that of the recovered cases. Half of the total reported cases recovered within three months of the first cases being announced by the President of Indonesia, Joko Widodo on March 2, 2020 (Ministry of Health RI, 2020g; Worldometer, 2020). The early detection of cases is still a challenge in Indonesia, and test facilities remain limited (Worldometer, 2020).

Public health experts have modeled COVID-19 in Indonesia and concluded that the reported cases by MOH RI are only approximately $10 \%-20 \%$ of actual cases. With low interventions, such as large-scale social distancing, and moderate intervention, such as mass testing and compulsory social distancing by closing schools and businesses, Indonesia should have detected 1.9 million or 1.1 million COVID-19 cases at the beginning of May 2020, respectively (Ariawan, Riono, Farid, Hafizah, \& Jusril, 2020). These estimated cases are far from the actual reported cases of approximately 14,000 (Ministry of Health RI, 2020f). In short, at the beginning of May 2020, official figures stated that Indonesia only had 14,000 COVID-19 cases in the country. However, the modeling suggests that this number is as high as 1.9 million.

Table 1. COVID-19 cases in Southeast Asia

\begin{tabular}{lrrrrrrr}
\hline \multicolumn{1}{c}{ Country } & $\begin{array}{c}\text { Total } \\
\text { test }\end{array}$ & $\begin{array}{r}\text { Test per } \\
\text { one million } \\
\text { population }\end{array}$ & $\begin{array}{c}\text { Number of } \\
\text { positive } \\
\text { cases }\end{array}$ & $\begin{array}{c}\text { Number of } \\
\text { deaths }\end{array}$ & $\begin{array}{c}\text { Number of } \\
\text { recovered } \\
\text { cases }\end{array}$ & $\begin{array}{c}\text { Case } \\
\text { fatality } \\
\text { rate (\%) }\end{array}$ & $\begin{array}{c}\text { Proportion } \\
\text { of recovery } \\
(\%)\end{array}$ \\
\hline Indonesia & 964,054 & 3,458 & 66,226 & 3,309 & 30,785 & 5,0 & 46 \\
Singapore & 757,746 & 129,506 & 45,140 & 26 & 41,002 & 0,1 & 91 \\
Philippines & 845,218 & 7,712 & 47,873 & 1,309 & 12,386 & 2,7 & 26 \\
Malaysia & 816,118 & 25,211 & 8,674 & 121 & 8,481 & 1,4 & 98 \\
Thailand & 286,008 & 4,099 & 3,025 & 56 & 2,854 & 1,9 & 94 \\
Vietnam & 275,000 & 2,825 & 369 & 0 & 341 & 0,0 & 92 \\
Myanmar & 85,689 & 1,575 & 316 & 6 & 245 & 1,9 & 78
\end{tabular}


Yeni, Najmah, Sharyn Davies | ASEAN Journal of Community Engagement | Volume 4, Number 1, 2020

\begin{tabular}{lrrrrrrr}
\hline \multicolumn{1}{c}{ Country } & $\begin{array}{c}\text { Total } \\
\text { test }\end{array}$ & $\begin{array}{c}\text { Test per } \\
\text { one million } \\
\text { population }\end{array}$ & $\begin{array}{c}\text { Number of } \\
\text { positive } \\
\text { cases }\end{array}$ & $\begin{array}{c}\text { Number of } \\
\text { deaths }\end{array}$ & $\begin{array}{c}\text { Number of } \\
\text { recovered } \\
\text { cases }\end{array}$ & $\begin{array}{c}\text { Case } \\
\text { fatality } \\
\text { rate (\%) }\end{array}$ & $\begin{array}{c}\text { Proportion } \\
\text { of recovery } \\
(\%)\end{array}$ \\
\hline Brunei & & & & & & & \\
Darussalam & 29,841 & 68,202 & 141 & 3 & 138 & 2,1 & 98 \\
Cambodia & 40,521 & 2,423 & 141 & 1 & 131 & 0,7 & 93 \\
Timor- & 1,568 & 1,189 & 24 & 0 & 24 & 0,0 & 100 \\
Leste & 1,8091 & 2,486 & 19 & 0 & 19 & 0,0 & 100 \\
Laos & & & & & & & \\
\hline
\end{tabular}

Note: Numbers of population in each country: Singapore $=$ six million; Indonesia $=270$ million; Philippines = 109 million; Malaysia = 32 million; Thailand = 70 million; Vietnam = 97 million; Myanmar = 54 million; Brunei $=440,000$; Cambodia $=17$ million; Timor-Leste $=1.3$ million; Laos $=7.3$ million.

Source: Report as of July 8, 2020 (Worldometer, 2020)

Epidemiological and statistical COVID-19 modeling is needed to solve the problem. Modeling is beneficial to measuring human resources and health facilities, including medical records, information health systems, and the readiness of laboratories in each province in Indonesia (Elyazar et al., 2020). According to Lutz et al. (2019) and Li et al. (2020), the accurate and timely prediction of infectious diseases can provide information for public health responses to seasonal pandemics in the future with appropriate guidance for early mitigation and prevention strategy. Previous studies on Severe Acute Respiratory Syndrome (SARS) outbreaks showed that the delay in controlling outbreaks for one week would make the number of cases three-fold higher than before and increase the duration of the epidemic to four weeks (Wallinga \& Teunis, 2004). An evidence-based or scientific policy base is necessary in all countries, especially in limited-resource countries with unequal chances to access health services, including Indonesia (Lutz et al., 2019). At the national level, MOH RI has established the Large-scale Social Guidelines of Restriction or Pembatasan Social Berskala Besar (PSBB) as one strategy for COVID-19 mitigation in Indonesia (Ministry of Health RI, 2020a).

South Sumatra, one of the provinces in Indonesia, is where the first two authors of this report came from. The study focuses on South Sumatra for three reasons. First, the first case in South Sumatra was announced on March 24, 2020, three weeks after the first case in Indonesia was reported. The detection of cases in South Sumatra is considered too late, as Jakarta can be reached by a 50-minute flight. Second, the number 
Yeni, Najmah, Sharyn Davies | ASEAN Journal of Community Engagement | Volume 4, Number 1, 2020

of samples tested is limited. For instance, Jakarta, with a population of over 10 million, has undertaken over 160,824 samples for the Polymerase Chain Reaction (PCR) test, whereas South Sumatra, with 8.5 million people, took only 4,745 samples for PCR test as June 3, 2020 (BPS, 2010; South Sumatra Provincial Government, 2020; Communication Informatics and Statistics Department of DKI Jakarta, 2020). Third, PSBB was implemented in South Sumatra, particularly in the cities of Palembang and Prabumulih, on May 12, 2020. PSBB is based on the regulation of MOH RI, number HK.01.07/Menkes/307/2020, (Ministry of Health RI, 2020d); therefore, an epidemiological model with SIR modeling is needed to estimate the number of COVID-19 cases in South Sumatra. This research also provides an epidemic curve, with and without public health intervention, as one measurement to determine the success of COVID-19 mitigation in South Sumatra.

This research argues the importance of including women's experiences in mitigating the impacts of COVID-19. Feminist research seeks to contribute to women's empowerment (Hesse-Biber, 2012). Women can contribute to the development of collective consciousness through their active participation, shared knowledge, and collaboration in the research itself (Crotty, 1998; Lykke, 2010). Kramarae and Spender (1992) further supported the notion that women have knowledge of and insight into their social life circumstances that enable them to transform themselves through knowledge construction. Empowering women, particularly from low-middle income families, as investigated by Biju (2020) in Kerala, India, can initiate communities to selfmanage the COVID-19 pandemic through mask and hand sanitizer production, the spread and promotion of the importance of social distancing and personal hygiene at the

grassroots level, and the provision of free counseling service to children during the unprecedented lockdown period (Biju, 2020). In limited-resource countries with limited access to COVID-19 tests and treatments, including Indonesia, women must be empowered to protect their family from COVID-19 transmission.

\section{Methods}

\subsection{Quantitative approach}

The prediction of COVID-19 cases was undertaken using the mathematical model of SIR. The SIR model was introduced by Kermack and McKendrick in 1927 as an epidemiological model to provide a simple way to explain the transmission of 
communicable diseases at the individual level, which can pass into three steps: susceptible, infected, and recovered (Institute for Disease Modeling, 2019). To undertake this modeling, we must know the average of doubling cases or the daily average for a case to infect other people, or transmission rate or $\beta$ and average days for recovery of one COVID-19 case, or recovery rate $(\Upsilon)$ (British International School Phuket, 2014; Collins \& Abdelal, 2018; Smith \& Moore, 2004).

$$
\begin{aligned}
& \frac{\mathrm{ds}}{\mathrm{dt}}=-\beta s i \ldots . . \\
& \frac{\mathrm{di}}{\mathrm{dt}}=\beta s i-\gamma \mathrm{i} \\
& \frac{\mathrm{dr}}{\mathrm{dt}}=\gamma \mathrm{i} \ldots \ldots . . . .
\end{aligned}
$$

Previous research showed that COVID-19 infection is assumed to occur within 12 hours for symptomatic cases and on the fourth and sixth day for asymptomatic cases (Ferguson et al., 2020). Infected cases with mild symptoms need two weeks to recover, whereas cases with severe symptoms require three to six weeks to recover (Aylward, Bruce; Liang, 2020). Therefore, for COVID-19 cases, we applied the assumption that one person infected with COVID-19 will transmit the virus to other people within approximately four days, and the recovery rate is assumed to take 14 days. This assumption is used to consider laboratory test delays for first and second samples, especially where laboratories are limited. South Sumatra's population is estimated to be approximately 8.6 million (BPS, 2018).

In our modeling, the prediction of cumulative cases of COVID-19 was based on three assumptions: 1) non-pharmaceutical intervention, 2) single intervention, and 3) multiple interventions. Non-pharmaceutical intervention is known as the public health approach without using any medication approach, such as health promotion. Single intervention is an intervention related to social distancing in working places, schools, and other mass gatherings. Multiple interventions involve non-pharmaceutical and single interventions, including other public health approaches, such as travel restriction (Ahmed, Zviedrite, \& Uzicanin, 2018). This intervention can reduce over $80 \%$ of imported cases from other countries or provinces in Indonesia to another country or province (Chinazzi et al., 2020). Multiple interventions with vaccination are the combination of multiple interventions with anti-retroviral therapy or prophylaxis therapy or availability of vaccination (Halloran et al., 2008; World Health Organization, 
Yeni, Najmah, Sharyn Davies | ASEAN Journal of Community Engagement | Volume 4, Number 1, 2020

2019). Yet, for a pandemic with a new strain of the virus, the third intervention is quite challenging as new vaccines or medicines take over six months of trials before they are used for randomized controlled trials at community levels (World Health Organization, 2019).

\subsection{Qualitative approach}

\subsubsection{Feminist Participatory Action Research (FPAR)}

Empowerment practices have a strong root in feminist research (Turner \& Maschi, 2015). Turner and Maschi (2015) argued that women are often positioned as powerless or marginalized in their social, cultural, and political spheres. FPAR, which was first introduced by Maguire (1987) and used by Lykes, Reid, and Frisby (2008), was selected as a suitable research methodology to facilitate the emergence of women's voices and collective empowerment leading to social action. Applying FPAR, we argued for the centrality of a woman's position as a subaltern, as a woman. We then co-constructed knowledge and engaged in the co-learning process through women's shared experiences, thoughts, and aspirations. Furthermore, even the often-silenced voices are enabled to develop a collective voice to raise their critical consciousness and to reflect and find solutions to their problems, leading to individual and collective actions (Brydon-Miller, Maguire, \& McIntyre, 2004). Previous research in health and social fields had been conducted in the context of empowering women, such as among Hmong women in Canada (Yoshihama \& Carr, 2002) and vulnerable women, such as those fleeing from violence at home (Jategaonkar \& Ponic, 2011). Previous and current studies, as both are participatory in nature, are open to use any data collection method that can enhance women's participation and social transformation.

Figure 1 summarizes the research cycle of FPAR in this study by adopting some principles and dimensions of FPAR on the basis of previous research by Lykes (2007, 2012), Maguire (1987), and Reid and Frisby (2008). Women in the general population, with different education backgrounds, social roles, and life contexts, are central to this study to allow for the construction of knowledge, critical understanding of the vulnerability of COVID-19 in a family, and the individual and collective consciousness needed to enhance COVID-19 awareness among children (Points 1, 2, and 3 in Figure 1). Moving to Points 3 and 4 of the cycle, the collective awareness of the importance of protecting family, particularly children, from COVID-19 was addressed. The mobile 
COVID-19 awareness movement for children (Penyuluhan keliling anak or PangLing) was critically examined by all-female volunteers as the beginning action to enable social transformation in practice, including being a volunteer, giving out masks and soaps, and educating children aged 5-12 about COVID-19 prevention.

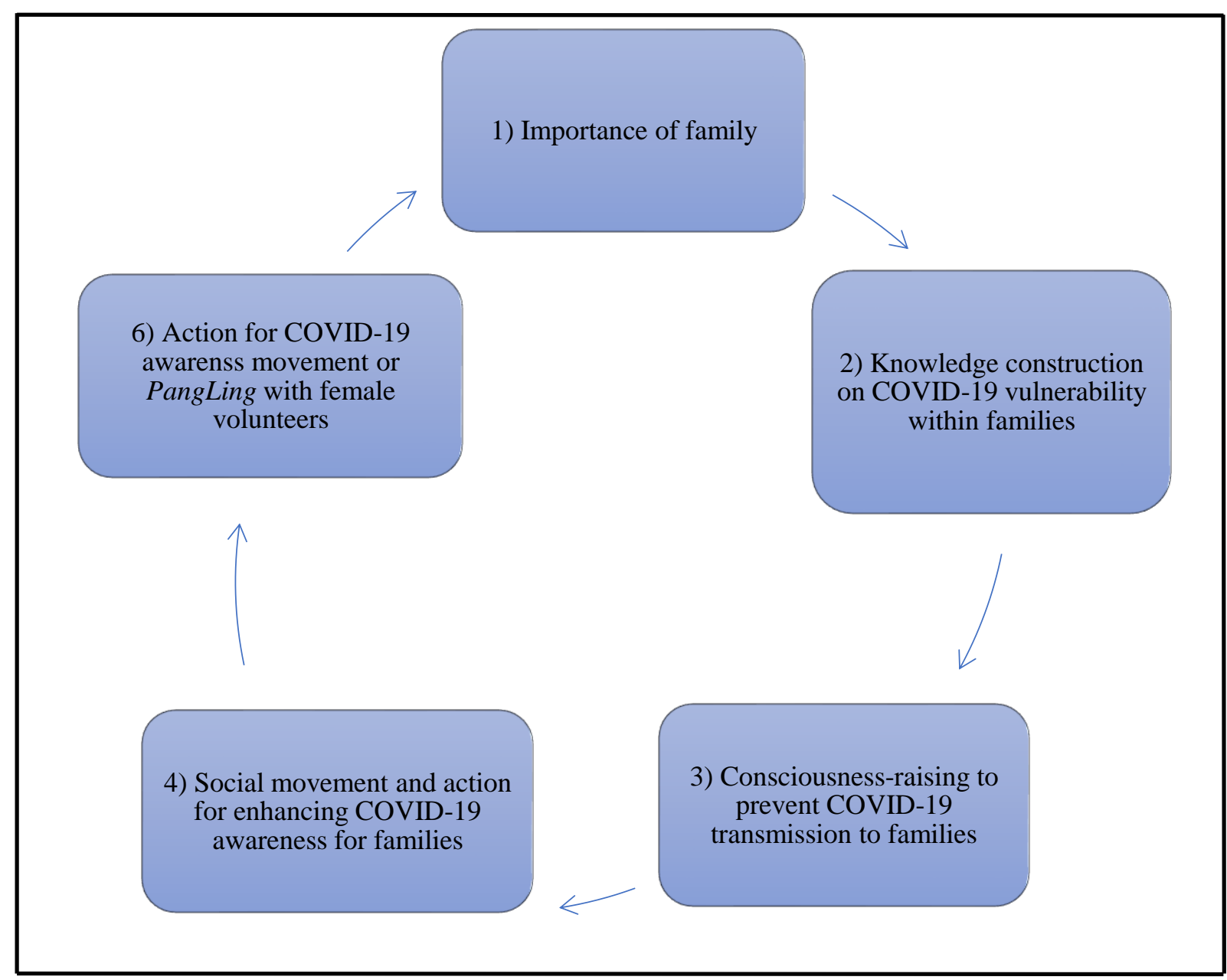

Fg. 1 Feminist Participatory Action Research (FPAR) cycle of enabling women to be involved in the movement of COVID-19 awareness for children in Palembang, South Sumatra

Sources: Lykes (2007; 2012), Reid and Frisby (2008)

Qualitative data were collected for over three months from April 2020 to June 2020. This research involved 10 women who participated in a social movement or PangLing voluntarily in a suburban area or kampung in Palembang (South Sumatra). The reflective notes during the fieldwork were reported every week by the second author and discussed with other authors to enhance the robustness of the research. Visual 
Yeni, Najmah, Sharyn Davies | ASEAN Journal of Community Engagement | Volume 4, Number 1, 2020

outcomes were also published on social media (Instagram: englishcamp_13ulu). In this study, we focused on the initial findings of the PangLing research project.

Authors' reflections were noted in field notes and included descriptions of research activities, details of participants involved, and overall assessments of the research process and participants' evaluations of activities. Reflection is an important aspect of data generation and analysis in FPAR (Lykes \& HershBerg, 2012). Based on the work of Regmi and Naidoo (2013), reflective analysis starts with a descriptive process, followed by assessment and analysis, and then evaluation and action.

\section{Result and Discussion}

\subsection{Indonesian context and COVID-19}

COVID-19 causes mild to severe respiratory symptoms in a short time caused by a coronavirus, namely, SARS-CoV 2 (Gorbalenya et al., 2020). This new virus is quite different from other viruses, such as SARS-CoV in 2003 and Middle East respiratory syndrome coronavirus in 2012, which also caused outbreaks of acute respiratory disorders. SARS-CoV 2, discovered in 2019, consists of a combination of many viruses isolated from human hosts and various types of bats (Gorbalenya et al., 2020). The main symptoms that appear are fever, dry cough, fatigue, and sputum production. Out of the 10 cases that show clinical symptoms, two will have difficulty breathing (Aylward, et al., 2020). Note that $80 \%$ of patients infected with COVID-19 will not have symptoms that are mild to moderate, but they can still transmit the virus (Li et al., 2020; The Novel Coronavirus Pneumonia Response Epidemiology Team, 2020).

Indonesia announced its first positive COVID-19 case on March 2, 2020. On April 9, 2020 (the 39th day), the confirmed cumulative number of positive COVID-19 cases in Indonesia had reached 3,923 (Ministry of Health RI, 2020f). On May 15, 2020, 16,496 positive COVID-19 cases were reported officially by MOH RI, with a death rate reaching 1,076 and a recovery rate of $20 \%$ or 3,803 cases, but with new cases increasing. On July 7, 2020, MOH RI reported that the number of confirmed new cases of positive COVID-19 in Indonesia had reached 1,268, with the cumulative number of cases reaching 66,226 cases (Figure 2). 


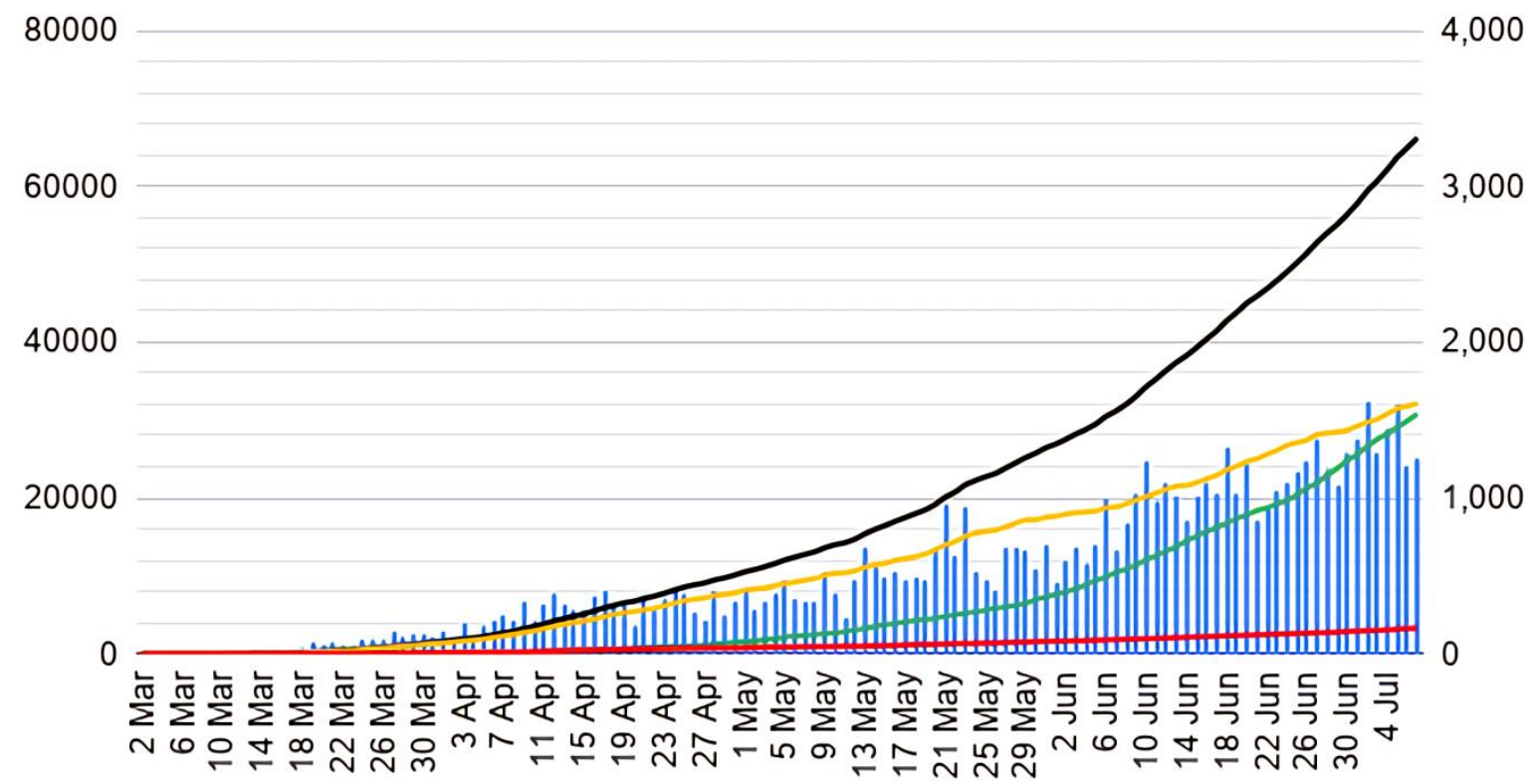

Note:__ New cases, __ Total cases, _ Active cases, _ Recovery, _ Death

Fg. 2 Daily incidence rates (new cases) in Indonesia Source: Kawal COVID-19, 2020; Ministry of Health RI, 2020b

\subsection{South Sumatra context and COVID-19}

Two patients under supervision or Pasien Dalam Pengawasan (PDP) in South Sumatra Province died on March 23, 2020. One PDP person, who died in the city of Palembang, was confirmed positive for COVID-19 on March 24, 2020. The press led by the Governor of South Sumatra revealed that another PDP person, who died in the city of Prabumulih, was confirmed positive for COVID-19 on March 28, 2020; this person was the head of the Prabumulih Hospital (Provincial Government of South Sumatra, 2020). The first two cases had a history of travel from Jakarta, Bogor, and/or Batam and thus were categorized as imported cases; both were over 50 years old and had a history of comorbidities, namely, diabetes (Putra, 2020; Septianto, 2020). Based on these data, South Sumatra Province had two positive cases of COVID-19 as of March 23, 2020.

The coverage testing and tracing of suspected COVID-19 cases are still low in this province; therefore, the positive results from all cases seem higher than those at the national level. Data (as of May 11, 2020) show that from all the completed specimen results in South Sumatra, 278 cases (51.7\%) were positive, and 260 samples (48.3\%) were negative (South Sumatra Provincial Government, 2020). The percentage of the positive cases of COVID-19 identified in South Sumatra is larger than that at the national 
Yeni, Najmah, Sharyn Davies | ASEAN Journal of Community Engagement | Volume 4, Number 1, 2020

level, where data from MOH RI reveal that out of the 116,358 specimens examined from 34 provinces in Indonesia, 14,265 (12.3\%) are positive for COVID-19 (Ministry of Health RI, 2020e).

\subsection{COVID-19 case prediction without intervention in South Sumatra}

Based on the prediction results, given that the first positive case of COVID-19 in South Sumatra is reported on the 11th day, the cumulative number of cases is predicted to reach 10 cases; on the 12th day, the number of cumulative cases is predicted to reach 12 cases (Figure 3). In the first two weeks after the positive case of COVID-19 was announced in South Sumatra, the prediction results had a difference that is not far apart (South Sumatra Provincial Government, 2020). However, in the following week, significant differences in the number of cumulative cases were found compared with the number of positive cases reported by the South Sumatra Provincial Government (Figure 3.

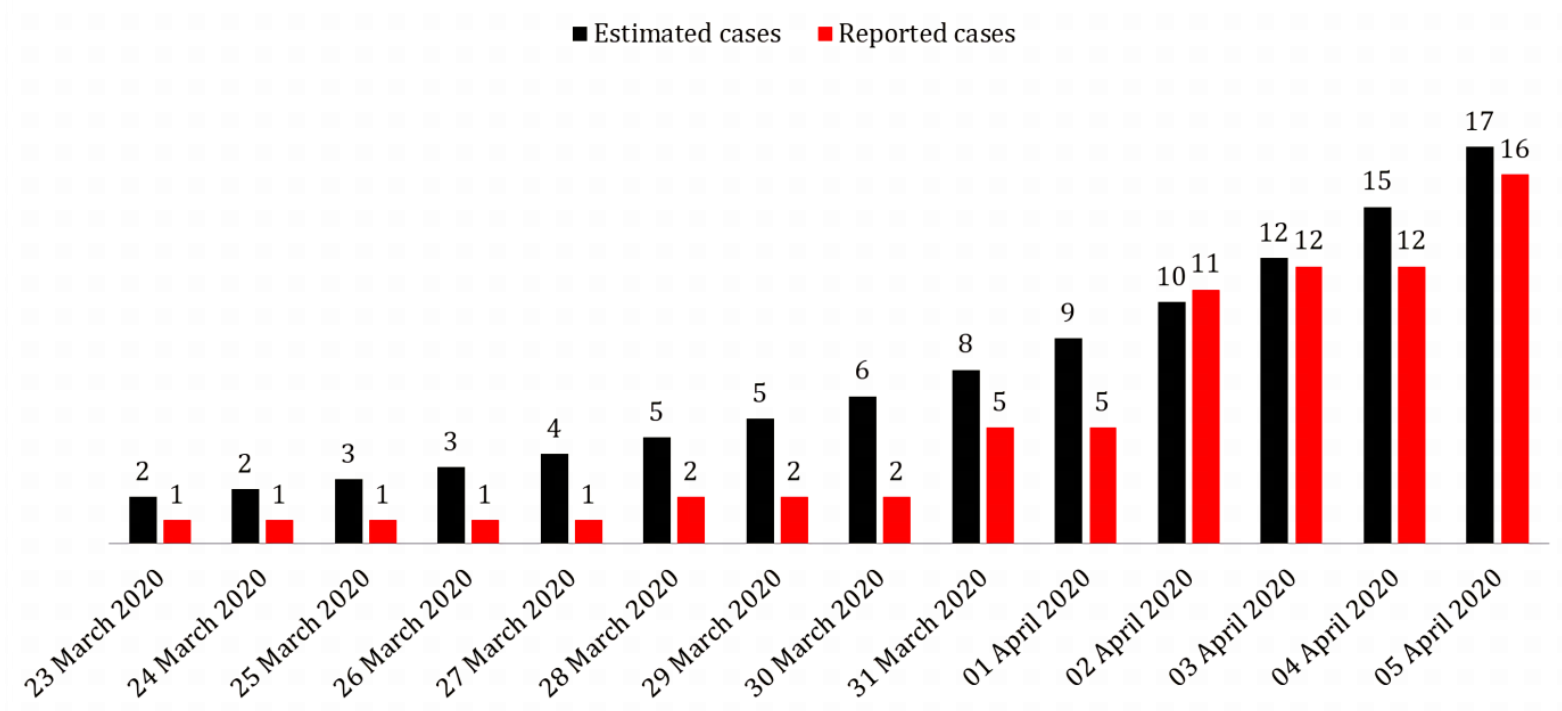

Fg. 3 Estimated number of positive cumulative cases of COVID-19 reported during the first 14 days in South Sumatra Province 


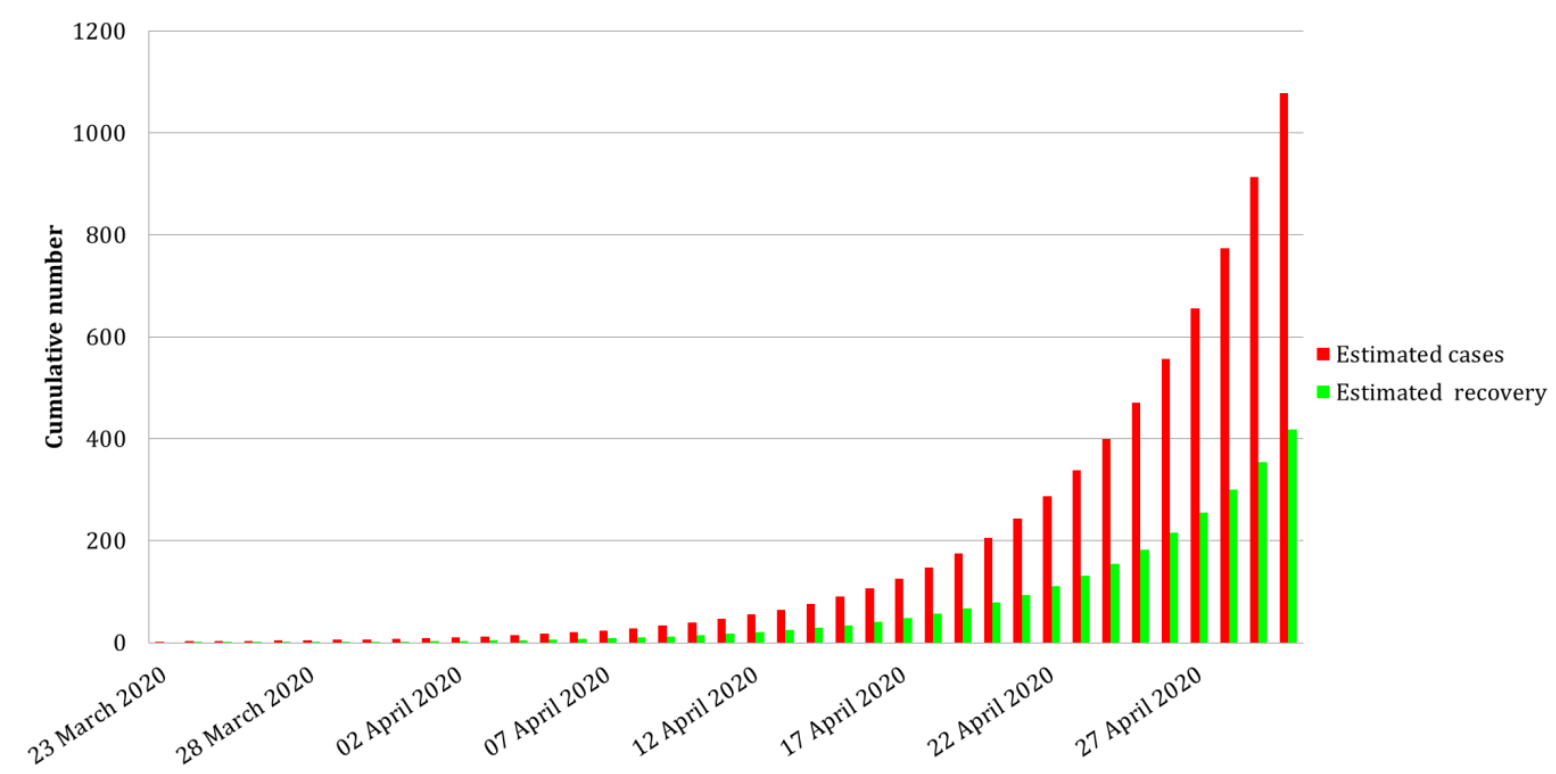

Fg. 4 Estimated number of cumulative cases recovered in South Sumatra Province on the last day of April 2020

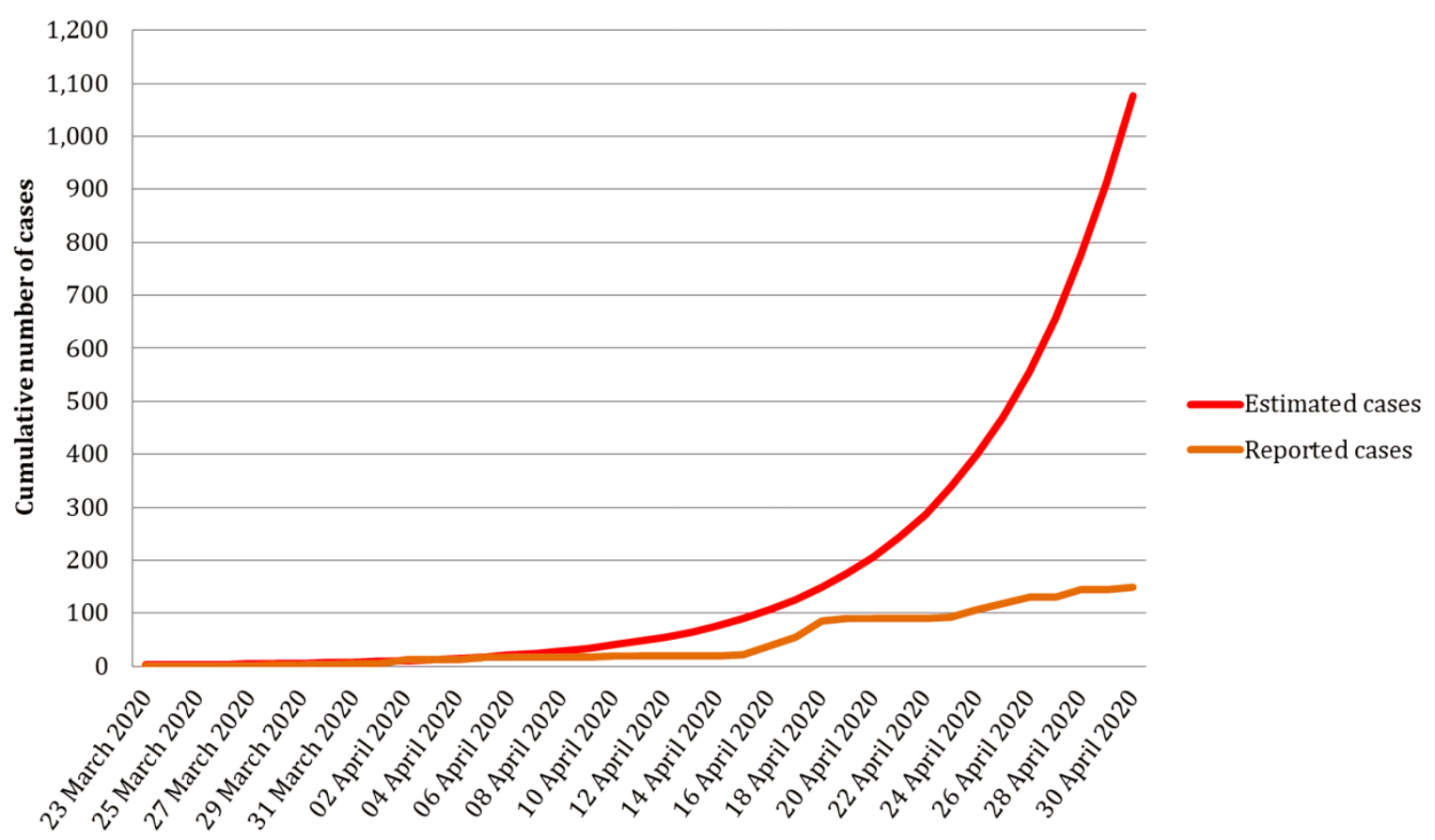

Fg. 5 Estimated cumulative number of positive cases of COVID-19 and cumulative number of positive cases reported in South Sumatra Province 
Yeni, Najmah, Sharyn Davies | ASEAN Journal of Community Engagement | Volume 4, Number 1, 2020

Without comprehensive intervention, the prediction results show that by the end of April 2020, the estimated number of COVID-19 cases in South Sumatra had reached more than 1,000 cases, with an estimated 400 patients recovered (Figures 4 and 5). However, on April 30, 2020, 150 new positive cases were detected, and the new number of recoveries was 23 people (South Sumatra Provincial Government, 2020). This finding indicates that early detection was still weak through testing and tracking in this province. As no sustainable interventions and public health approaches exist, the prediction results show that one-third of the total population in South Sumatra will be infected with COVID-19 by the end of June 2020 (Figure 6). For the record, until early May 2020, no PSBB intervention was observed in South Sumatra, similar to other provinces, such as DKI Jakarta and West Java (Ministry of Health RI, 2020c).

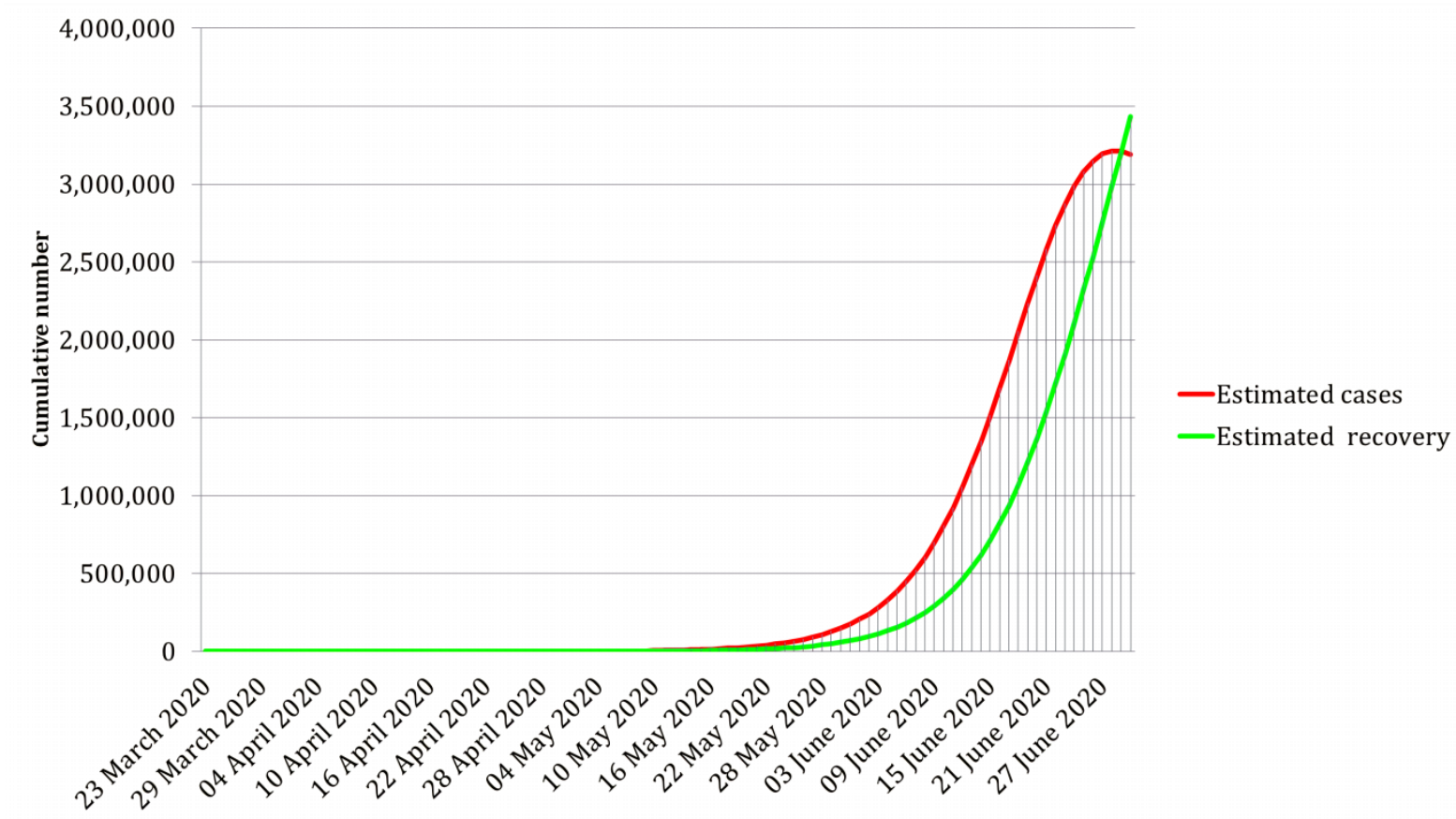

Fg. 6 Predicted peak results of the COVID-19 pandemic in South Sumatra Province without intervention from the provincial government

\subsection{Predicted number of COVID-19 cases without and with intervention in South Sumatra}

Based on prediction results, the implementation of a single intervention or a single intervention in the form of social distancing can only reduce the number of cumulative cases from 3.2 million cases to 2.5 million cases (Figure 7). A significant reduction in the number of cumulative cases occurred during the implementation of multiple 
interventions where the number of cases decreased from 3.2 million cases to 500,000 cases at the height of the pandemic (Figure 7).

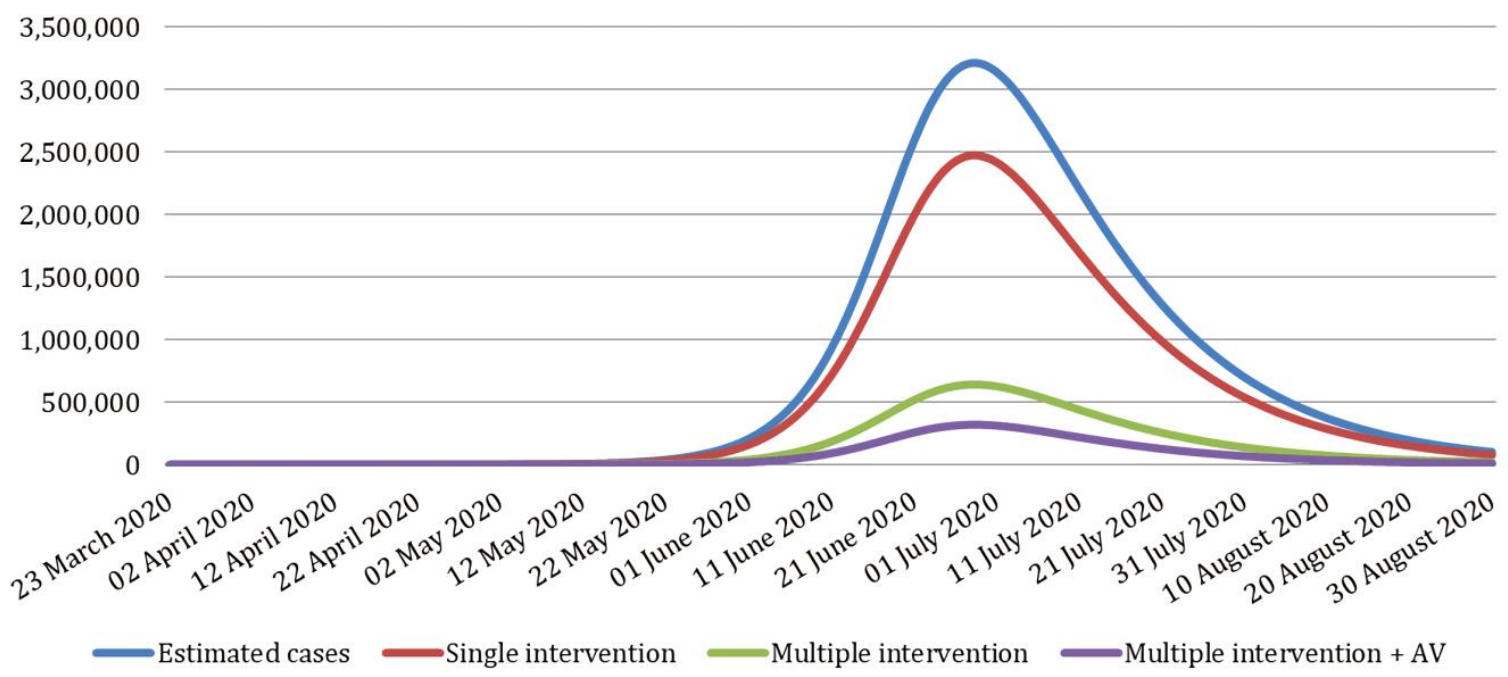

Fg. 7 Predictions of positive COVID-19 cases in South Sumatra Province according to several types of interventions

Note: 1) No intervention: no intervention; 2) Single intervention: a single intervention; 3) Multiple interventions: multiple interventions; 4) Multiple intervention with anti-virus treatment: multiple interventions and anti-virus and vaccination treatments

3.5. Need for treatment rooms and Intensive Care Units (ICUs) at the height of the Pandemic without multiple interventions

Prediction results based on the epidemic curve modeling show that as many as 600,000 cases will require hospitalization during the peak of the pandemic. Based on the assumption of the CFR COVID-19 in Indonesia, the number of deaths will reach half of the number of patients receiving care in hospital if patient care support devices, such as ventilators, isolation rooms, and ICUs, are still limited (Figure 8).

At the height of the pandemic, approximately 250,000 people are predicted to have died from COVID-19 (Figure 8). On July 16, 2020, the South Sumatra Provincial Government reported that out of the 2,829 people who tested positive for COVID-19, 135 died. Therefore, COVID-19 can be another cause of death today, approximately $4.7 \%$ of the total cases, apart from other five most common causes of death, such as stroke (17.31\%), ischemic heart disease (15.91\%), diabetes (5.98\%), tuberculosis (4.76\%), and 
Yeni, Najmah, Sharyn Davies | ASEAN Journal of Community Engagement | Volume 4, Number 1, 2020

cirrhosis (4.07\%) per 100,000 population (Institute for Health Metrics and Evaluation, 2017; South Sumatra Provincial Government, 2020).

Based on the analysis, one in 10 patients needs ICU treatment, as exhibited from the total prediction of the number of patients who need hospital treatment. The data show that the number of patients who need care and ICU treatment exceeds the availability of beds and ventilators. Figure 9 illustrates that by the end of June, the South Sumatra Provincial Government would need almost one million hospital beds, and $10 \%$ of these cases must be treated in ICUs; however, the MOH RI data show that in 2018, 9,045 beds were available in South Sumatra Province (Pusdatin Ministry of Health RI, 2019), and 281 ventilator units were spread across the province. This information is based on the data from the Task Force for the COVID-19 Handling Acceleration (Databoks, 2020) and excludes extra beds in guesthouses for South Sumatra athletes.

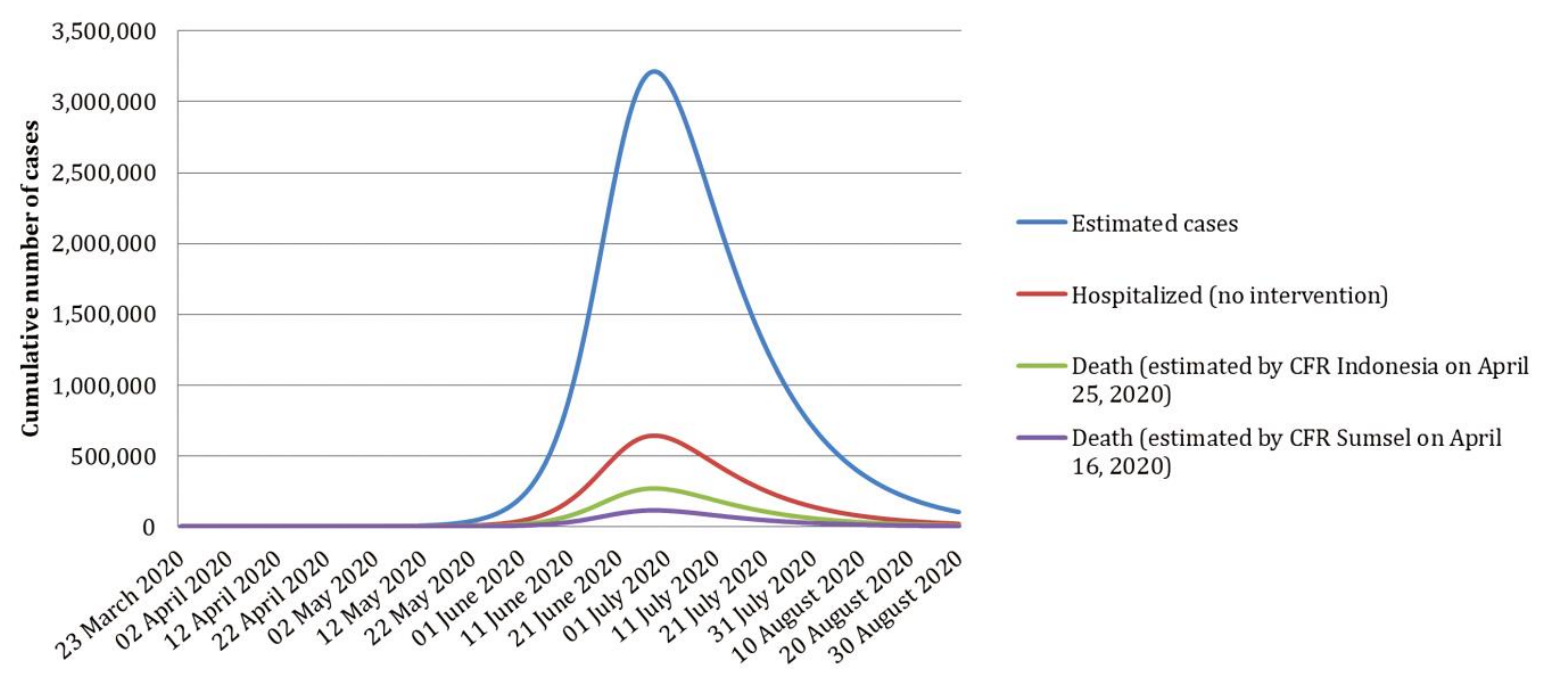

Fg. 8 Prediction of the positive cases of COVID-19, cases needing treatment, and cases of death in South Sumatra Province

Note: 1) Estimated cases: prediction of cases that are infected/contracting COVID-19; 2) Hospitalized: COVID-19 patients who need hospital treatment; 3) Death (estimated by CFR Indonesia): The number of deaths related to Covid-19 calculated using the Indonesian CFR assumption 4) Death (estimated by CFR

Sumsel): The number of deaths related to Covid calculated using the Sumsel CFR assumption 


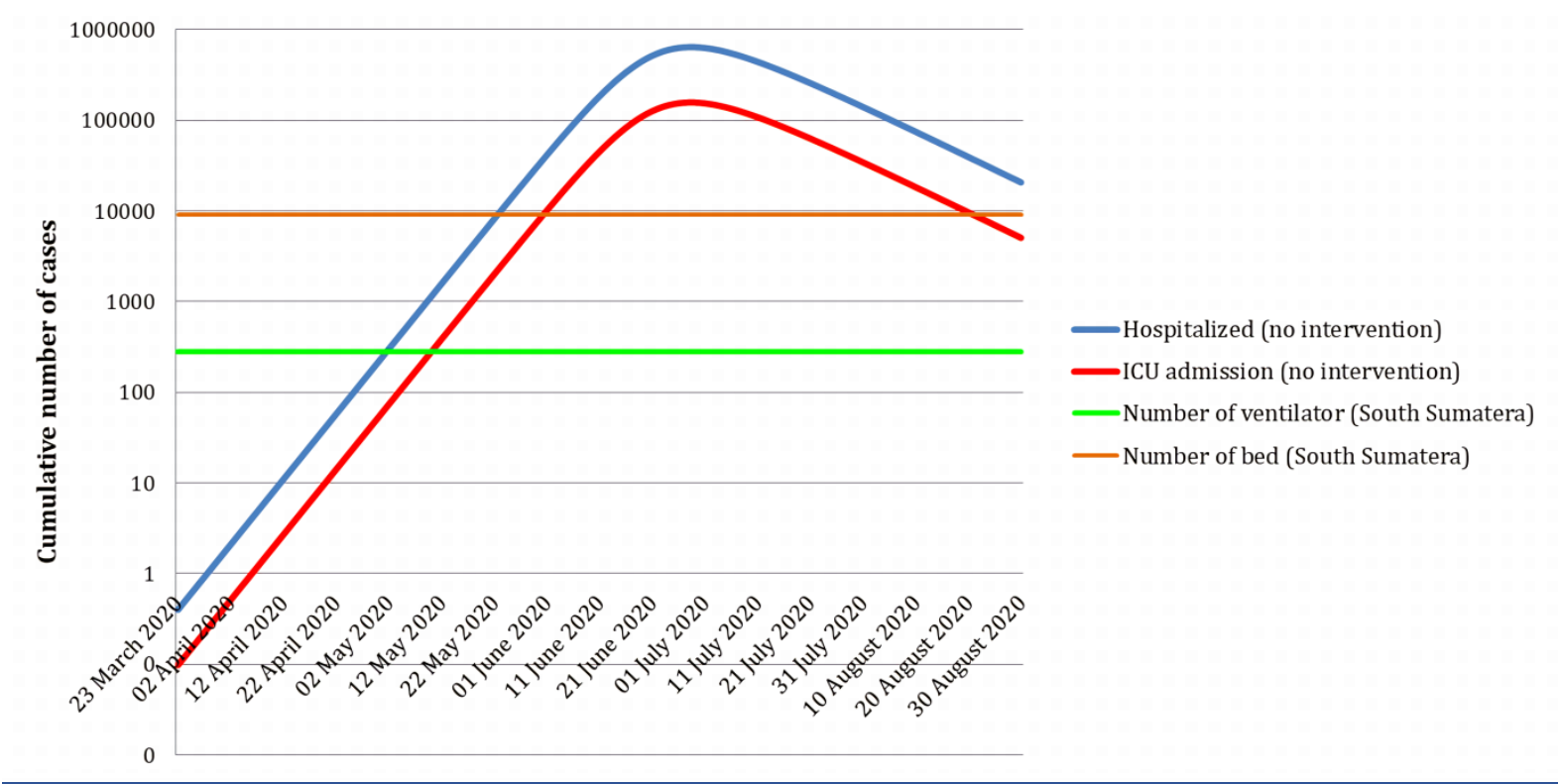

Fg. 9 Prediction of the number of cases that need hospital treatment for the availability of ventilators and beds in South Sumatra Province

3.6. Need for treatment rooms and ICUs at the height of the Pandemic with multiple interventions

The results of modeling use the assumption of multiple interventions where as much as $80 \%$ of the number of cases will be reduced if multiple interventions are conducted (Chinazzi et al., 2020). The modeling results show that with multiple interventions, the number of COVID-19 cases requiring hospital treatment is reduced from the initial estimate of 128,568 cases. Moreover, the estimated number of cases requiring ICU treatment is 31,499 cases (Figure 10 ). 
Yeni, Najmah, Sharyn Davies | ASEAN Journal of Community Engagement | Volume 4, Number 1, 2020

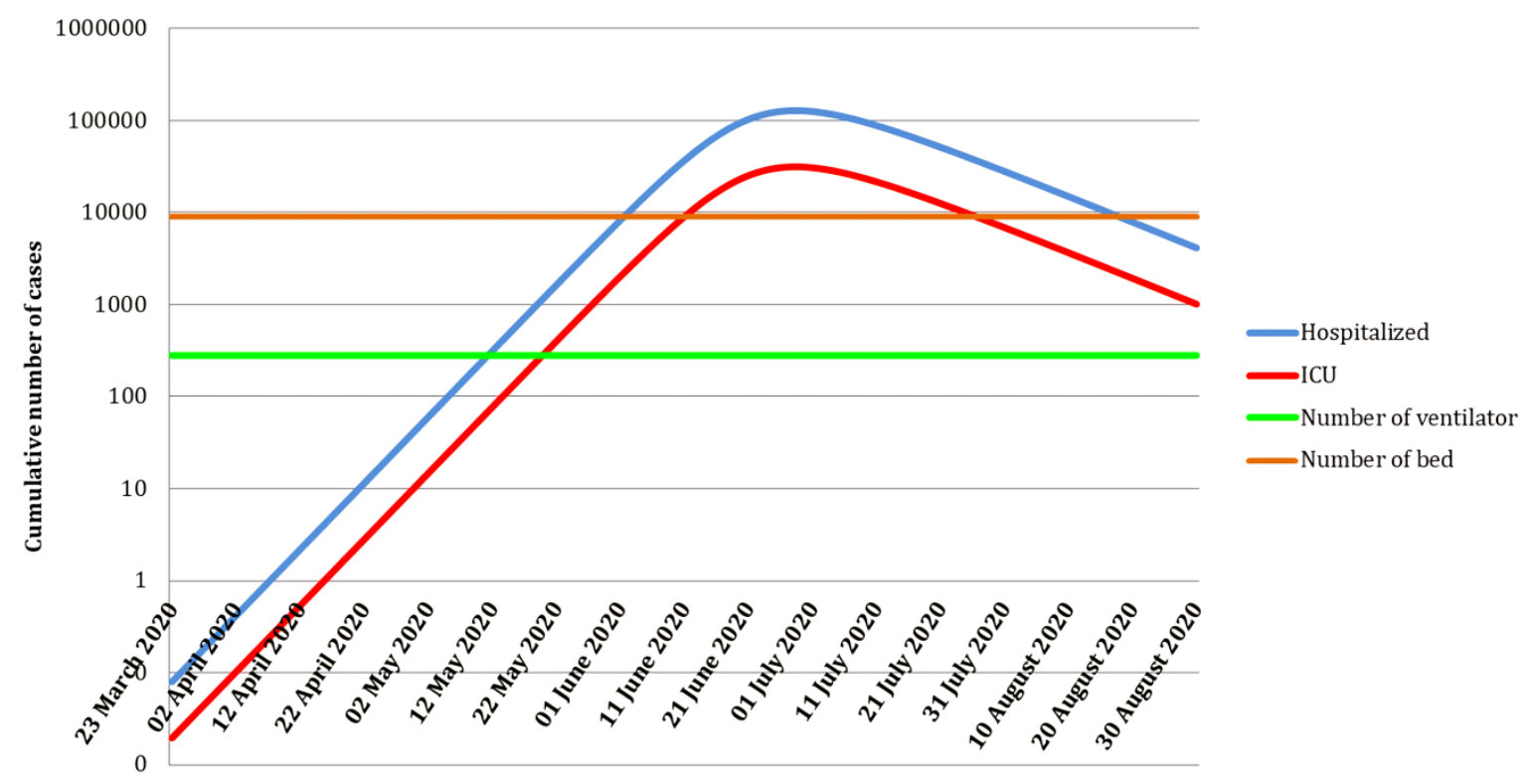

Fg. 10 Prediction of the number of cases that need hospitalization for the availability of ventilators and beds with multiple interventions

\subsection{Lessons to learn for Indonesia}

The spread of COVID-19 cases in Indonesia is at the "local transmission" level. That is, every citizen can be infected with COVID-19, without having to travel to areas with red zones or countries with already widespread cases. The Indonesian Health System is still overlapping between the central and regional governments and thus requires the development of a COVID-19 mitigation strategy based on the epidemic curves in each province (Djalante et al., 2020).

The current study shows that in South Sumatra, the research setting, one-third of the people are at risk of being infected by COVID-19 without comprehensive intervention. Prediction results and cases differ quite significantly, with only $5 \%-10 \%$ of cases being detected compared with the estimated COVID-19 cases in South Sumatra. Therefore, early detection through COVID-19 tests and tracking in South Sumatra Province remains weak and thus reflects the condition in Indonesia (Soeriaatmadja, 2020). The current prediction indicates that the real number of the positive cases of COVID-19 is far more likely than the reported cases by the South Sumatra Provincial Government. The "denial" of cases of COVID-19 in Indonesia in early February 2020 might have led to the delay in preventing COVID-19 in the country, including that in other 34 provinces (Lindsley \& Mann, 2020). Without overall intervention by the government accompanied 
by community participation, Indonesia can be the third virus hotspot in Asia (Riono, cited in Massola, 2020).

South Sumatra must act fast to prevent the surge in the number of COVID-19 cases. Our study considers that cases may peak in late June 2020 (Yeni, Najmah, \& Davies, 2020a). However, with the current improvement in COVID-19 tests and coverage in Indonesia, the peak epidemic curve can move to following months, September or October, with a late response of COVID-19 (Riono, cited in Massola, 2020). Sadly, the risk of mortality due to COVID-19 and the complication of non-communicable diseases seriously threaten the age group of over 50 years in Indonesia and other countries (Ferguson, 2020; Ministry of Health RI, 2020b).

\subsection{Reflecting the urgent needs of Hospital beds}

Based on the results of our predictions, the assumption is that $20 \%$ of patients in South Sumatra will require hospital treatment (Tamara Pilishvili, Razzaghi, Reed, Ritchey, \& Sauber-Schatz, 2020). Therefore, the percentage of the number of positive cases of COVID-19 in South Sumatra requiring hospitalization will reach 600,000 people by the end of June 2020 without the intervention of a public health approach. This number will exceed the capacity of hospitals in South Sumatra, as the number of available beds in the province is 9,045 units, whereas that in other inpatient rooms [ICU, High Care Unit, Intensive Coronary Care Unit, Respiratory Intensive Care Unit, Neonatal Intensive Care Unit, Pediatric Intensive Care Unit, and Isolation] is 979; these quantities exclude the extra beds prepared by the South Sumatra Provincial Government (Pusdatin Minstry of Health RI, 2019). If multiple interventions are conducted, then the number of cases that need treatment may be reduced to one-tenth of the estimated initial cases that require ICU care that is approximately 31,000 people.

\subsection{Reflecting Indonesia's effort in mitigating COVID-19 with other Countries}

As observed in several countries, the virus spreads quickly. For instance, it spread to all parts of China within 30 days of the first case being discovered (The Novel Coronavirus Pneumonia Response Epidemiology Team, 2020). Restricting mobilization to and from an area and crowd restrictions, such as working at home and limiting school movements, can slow the spread of COVID-19 from one to three weeks (Ahmed et al., 2018; Chinazzi et al., 2020). However, without changes in individual behavior, such as 
Yeni, Najmah, Sharyn Davies | ASEAN Journal of Community Engagement | Volume 4, Number 1, 2020

washing hands with soap, keeping physical distance, offsetting by early detection of cases, and rapid tracking of COVID-19 cases, including isolating oneself or being quarantined at home, the effectiveness of limiting human movement (including PSBB in the Indonesian context) will not be effective in reducing the number of cases over time (Chinazzi et al., 2020; The Novel Coronavirus Pneumonia Response Epidemiology Team, 2020; World Health Organization, 2019). Social distancing, such as PSBB in Indonesia, is predicted to be less effective in reducing the number of new COVID-19 cases if R0 continues to increase and is not conducted at the beginning of the pandemic, before the cases soar (Ahmed et al., 2018; Milne, Kelso, Kelly, Huband, \& McVernon, 2008).

Many countries have successfully implemented multiple interventions to protect public health amid the COVID-19 pandemic. Vietnam and Thailand are examples of countries that have successfully carried out epidemic prevention using the approach of several public health interventions together with social-physical intervention programs. The successful prevention can be seen from the number of positive cases and low mortality rate that occurred in Vietnam and Thailand (Table 1) (Worldometer, 2020). Vietnam did not apply lockdown to all cities where infected cases occurred but closed all places and canceled all potentially crowded events, such as schools, festivals, and conferences (Nguyen \& Vu, 2020). On January 30, 2020, Vietnam refused entry of all foreigners from China or other countries who had transit in China within 14 days of their arrival in Vietnam. All tourists who come to Vietnam must be quarantined in a centralized facility for 14 days where food and room cleaning facilities are provided during their isolation routinely (Nguyen \& Vu, 2020). Timely communication about the development of outbreaks from the government and the media, combined with the latest research on new viruses by the Vietnamese science community, is a rapid strategy for Vietnam to respond to its public health crisis (La et al., 2020).

Another country in Southeast Asia, Thailand, is an example where lockdown was implemented to prevent the spread of COVID-19 by closing their international flights since early March 2020 (Medina, 2020). The intervention continued with significant restrictions on educational institutions, markets, and international travel on March 18, 2020 (Kanok-Nukulchai, 2020). In terms of disease mitigation, Thailand established a center in charge of managing trips in and out of the kingdom with more stringent screening, quarantine, and monitoring measures, including the opening of free mask 
outlets for residents and the imposing of imprisonment or fines for communities where rules for early vigilance are violated (Bangkok Post, 2020).

The combination of early case tracking and multiple public health interventions, such as isolation or independent quarantine at home, and changes in behavior, such as washing hands and wearing masks, can reduce transmission and the effects of influenza pandemics. However, case tracking requires adequate resources to survive after the initial pandemic phase because the numbers of cases and contacts grow exponentially in a short time. Case tracking can be applied in several conditions or objectives, such as case identification in high-risk groups, to allow early treatment, delay widespread dissemination in small isolated communities or in aircraft settings to prevent import cases (Fong et al., 2020).

What should be considered for the Indonesian context? The tight closure of interprovincial and international human mobilization pathways requires the commitment of local governments to reduce the case of imports from other provinces or countries and establish epidemic curves in collaboration with cross-sectors, especially those that will be affected economically by the closure of this transport route (World Health Organization, 2019). This action must be performed while considering COVID-19 case screening with rapid tests with an accuracy rate of approximately $30 \%$. Note that body temperature measurements are less effective for the early detection of COVID-19 cases.

\subsection{What does the Indonesian community need to do?}

Most countries have entered or are preparing for the New Normal Life phase, with the following records: 1) no more deaths due to COVID-19; 2) no new positive cases of COVID-19; 3) recovery rate exceeds 95\% (Yeni et al., 2020b). Indonesia is unique, as it plans to implement this phase while the epidemic curve graph is still showing an increasing trend; cases of death and new positive cases of COVID-19 are still recorded; the cure rate remains approximately $50 \%$.

In South Sumatra, especially in the city of Palembang, the three points above must be resolved immediately. Data indicate that since the implementation of PSBB, the numbers of new cases and deaths have been continuously increasing; the number of patients who recovered is also still far from 95\% (Yeni et al., 2020a; Yeni et al., 2020b). We must evaluate the prevention efforts that have been made so far in South Sumatra. 
Yeni, Najmah, Sharyn Davies | ASEAN Journal of Community Engagement | Volume 4, Number 1, 2020

The readiness of Indonesia, especially in South Sumatra, is still far below that of several neighboring countries. WHO predicts that COVID-19 will move from a pandemic to an endemic. That is, the COVID-19 virus will remain for a long time in a country. Therefore, without knowing which population has been infected with COVID-19, due to the limited access to COVID-19 tests, family empowerment is urgently needed, so that mothers and daughters can break the chain of virus transmission. For instance, at the community level, our study shows the need for women's empowerment to engage in COVID-19 awareness for kids or PangLing in their closest neighborhood in their own suburban or kampung. The initial finding of the current research indicates that with the critical awareness of 10 women in the PangLing Movement, the social movement can provide health education, masks, and soaps to over 500 kids. Over 10 donors became involved in our activities to provide masks and soaps after we posted our activities on social media. The evaluation of this research is still an on-going process.

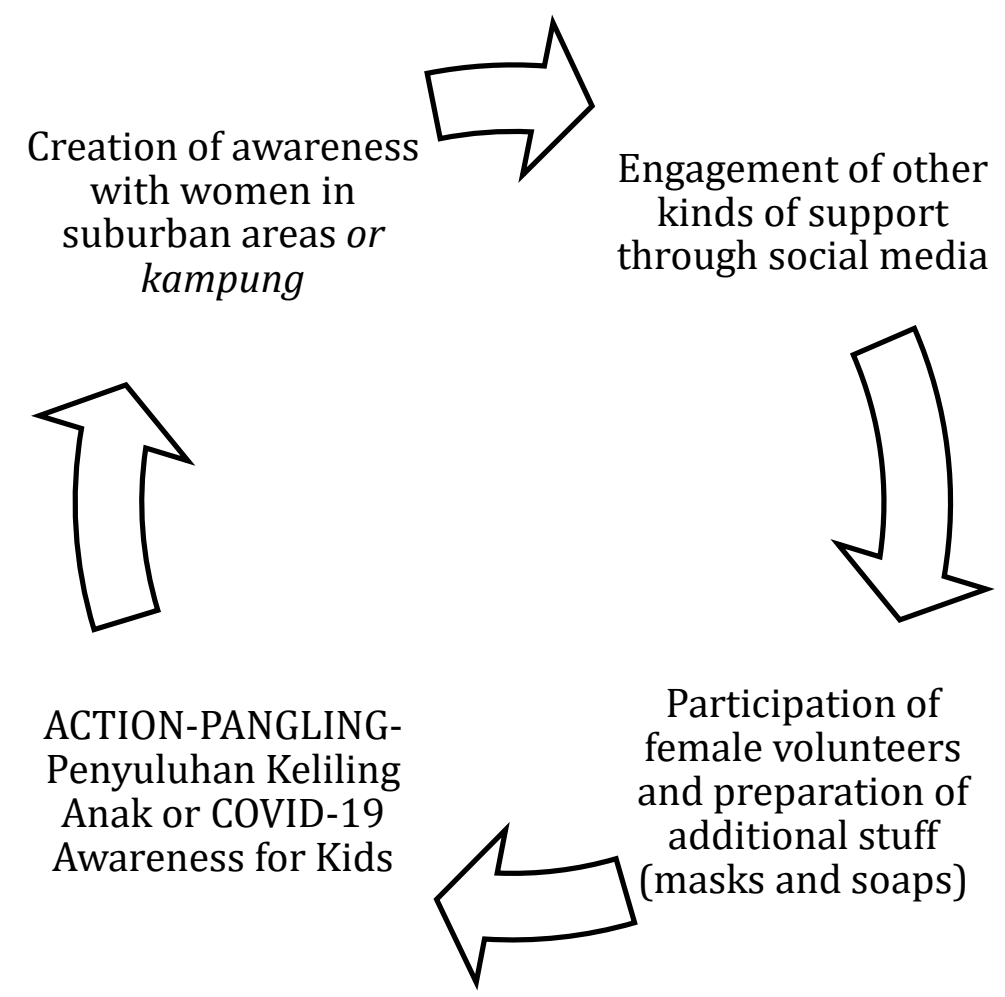

Fg. 11 Cycle of feminist-PAR in COVID-19 awareness for kids in a suburban area in Palembang (Kampung 13 Ulu and 14 Ulu)

Note: Activities of PangLing can be access here: https://www.instagram.com/englishcamp_13ulu/?hl=en 


\section{Conclusion}

This study has two main conclusions. First, modeling through a quantitative approach shows that a high number of COVID-19 cases are not detected in South Sumatra. Only $5 \%-10 \%$ of the total cases could be detected by the South Sumatra Provincial Government at the end of April 2020, and one-third of the total population in South Sumatra would be infected with COVID-19 by the end of June 2020. The implementation of multiple interventions is needed to reduce transmission rates, including that of social distancing, in combination with other public health interventions, such as travel restrictions, hand washing, and mask wearing. In addition, expanding the scope of testing, contact tracing, and case isolation can help map the spread of COVID-19 cases, and this mapping can help reduce local transmission.

Second, through a qualitative approach, women's empowerment within a neighborhood can be one core intervention to the mass education of COVID-19 awareness in small groups of community in suburban areas or kampung. In a small system, the prevention of COVID-19 transmission in South Sumatra will be more effective with discipline that starts from everyone to adhere to the health protocols (diligently washing hands, wearing masks, and keeping a distance). With discipline at the family level, we can feel the impact at the community level. The government's commitment to discipline in enforcing regulations and health protocols that have been made will try built at the level of Individual - Family - Community can run as expected. Furthermore, empowering the grass-root at local governments in Indonesia is urgently needed. For instance, the kelurahan level (local subdistrict office) with the Lurah (the leader of kelurahan) and Rukun Tetangga and mobilizing posyandu (maternal and child health community centers) cadres and educated communities, particularly women with diverse backgrounds, should cooperate with the government to monitor the continuity of COVID-19 handling on a small scale.

The limitations of this study include the fact that modeling has not been considered in investigating vulnerable groups, such as the elderly, children, sufferers of chronic diseases, and people with disabilities or people traveling domestically, especially at the end of the fasting month. 
Yeni, Najmah, Sharyn Davies | ASEAN Journal of Community Engagement | Volume 4, Number 1, 2020

\section{Author Contribution}

All authors conceived of the presented idea. Najmah and Sharyn Graham Davies developed the theory and Yeni performed the computations. Najmah and Yeni verified the analytical methods. Sharyn Graham Davies supervised the findings of this work. All authors discussed the results and contributed to the final manuscript.

\section{Acknowledgments}

We acknowledge the Dean of the Public Health Faculty, the Centres of Research and Community (LPPM), and the Rector of UNSRI for supporting Najmah and Yeni.

\section{References}

Ahmed, F., Zviedrite, N., \& Uzicanin, A. (2018). Effectiveness of workplace social distancing measures in reducing influenza transmission: A systematic review. $B M C$ Public Health, 18(1).

https://doi.org/10.1186/s12889-018-5446-1

Ariawan, I., Riono, P., Farid, M., Hafizah, \& Jusril. (2020). COVID-19 Modelling Scenarios Indonesia. In Bappenas. Jakarta.

Aylward, Bruce (WHO); Liang, W. (PRC). (2020). Report of the WHO-China Joint Mission on Coronavirus Disease 2019 (COVID-19). In The WHO-China Joint Mission on Coronavirus Disease 2019 (Vol. 2019).

https://www.who.int/docs/default-source/coronaviruse/who-china-joint-missionon-covid-19-final-report.pdf

Bangkok post. (2020, April 3). Curfew starts on Friday. Bangkok Post.

https://www.bangkokpost.com/thailand/general/1891910/curfew-starts-onfriday?fbclid=IwAR0VS4QJRITTY75RtbfGsh-UXFbei-

Yki5DaD4Miqe7Zq5CCyiuqk3mXC-g

Bedford, J., Enria, D., Giesecke, J., Heymann, D. L., Ihekweazu, C., Kobinger, G.,... \& Ungchusak, K. (2020). COVID-19: towards controlling of a pandemic. The Lancet, 395(10229), 1015-1018.

Central Statistics Agency. (2010). Jumlah dan Distribusi Penduduk (Population Number and Distribution).

https://sp2010.bps.go.id/index.php 
Central Statistics Agency. (2018, October 29). Proyeksi Penduduk Kabupaten/Kota Provinsi Sumatera Selatan (Projection of Regency / City Population of South Sumatra Province).

https://sumsel.bps.go.id/statictable/2018/10/29/108/proyeksi-penduduksumatera-selatan-2010-2020.html

Brydon-Miller, M., Maguire, P., \& McIntyre, A. (Eds.). (2004). Traveling companions: Feminism, teaching, and action research. London, UK: Greenwood Publishing Group. British International School Phuket. (2014, May 17). Modelling Infectious Diseases. https://ibmathsresources.com/2014/05/17/modelling-infectious-diseases/

Chinazzi, M., Davis, J. T., Ajelli, M., Gioannini, C., Litvinova, M., Merler, S., ... Vespignani, A. (2020). The effect of travel restrictions on the spread of the 2019 novel coronavirus (COVID-19) outbreak. Science (New York, N.Y.).

https://doi.org/10.1126/science.aba9757

Collins, D. J., \& Abdelal, N. (2018). Spread of Disease. Calculate.

https://calculate.org.au/wp-content/uploads/sites/15/2018/10/spread-of-

disease.pdf

Communication Informatics and Statistics Department of DKI Jakarta. (2020). Perkembangan covid-19 di Jakarta per 11 mei 2020 (Development of covid-19 in Jakarta per 11 may 2020).

https://corona.jakarta.go.id/id

Crotty, M. (1998). The foundations of social research: Meaning and perspective in the research process. London, UK: SAGE.

Databoks. (2020, April 14). What is the Availability Number and Need of Ventilators in Indonesia? Databoks.

https://databoks.katadata.co.id/datapublish/2020/04/14/berapa-jumlahketersediaan-dan-kebutuhan-ventilator-di-indonesia

Djalante, R., Lassa, J., Setiamarga, D., Mahfud, C., Sudjatma, A., Indrawan, M.,... \& Gunawan, L. A. (2020). Review and analysis of current responses to COVID-19 in Indonesia: Period of January to March 2020. Progress in Disaster Science, 6, 100091. https://doi.org/10.1016/j.pdisas.2020.100091 
Yeni, Najmah, Sharyn Davies | ASEAN Journal of Community Engagement | Volume 4, Number 1, 2020

Elyazar, Iqbal; Lestari, Karina Dian, Ekawati, Lenny Lia, Lina, R. N. (2020, May 8). Indonesia belum punya kurva epidemic Covid-19: Indonesia does not yet have the Covid-19 epidemic curve: We must carefully read the government's claims of a new case slowing down. The Conversation.

https://theconversation.com/indonesia-belum-punya-kurva-epidemi-covid-19-kitaharus-hati-hati-membaca-klaim-pemerintah-kasus-baru-melambat-

137497?utm_source=whatsapp\&utm_medium=bylinewhatsappbutton\&fbclid=IwAR 2QwsoKZs8KaakUt5irWlWWiJLuSpo2cuZibIYPb2DWBj4d

Ferguson, N. M., Laydon, D., Nedjati-Gilani, G., Imai, N., Ainslie, K., Baguelin, M., ... Ghani, A. C. (2020). Impact of non-pharmaceutical interventions (NPIs) to reduce COVID-19 mortality and healthcare demand. Imperial.Ac.Uk, (March), 3-20.

https://doi.org/10.25561/77482

Fong, M. W., Gao, H., Wong, J. Y., Xiao, J., Shiu, E. Y. C., Ryu, S., \& Cowling, B. J. (2020). Nonpharmaceutical Measures for Pandemic Influenza in Nonhealthcare SettingsSocial Distancing Measures. Emerging Infectious Diseases, 26(5), 976-984.

https://doi.org/10.3201/eid2605.190995

Gorbalenya, A. E., Baker, S. C., Baric, R. S., de Groot, R. J., Drosten, C., Gulyaeva, A. A., ... Ziebuhr, J. (2020). The species Severe acute respiratory syndrome-related coronavirus: classifying 2019-nCoV and naming it SARS-CoV-2. Nature Microbiology, 5(4), 536-544.

https://doi.org/10.1038/s41564-020-0695-Z

Halloran, M. E., Ferguson, N. M., Eubank, S., Longini, I. M., Cummings, D. A. T., Lewis, B., ... Cooley, P. (2008). Modeling targeted layered containment of an influenza pandemic in the United States. Proceedings of the National Academy of Sciences of the United States of America, 105(12), 4639-4644.

https://doi.org/10.1073/pnas.0706849105

Hesse-Biber, S. N. (2012). Feminist research, exploring, interrogating and transforming the interconnections of epistemology, methodology and method. In S. N. Hesse-Biber (Eds.), The handbook of Feminist Research. London, UK: SAGE.

Institute for Health Metrics and Evaluation. (2017). Global Burden Disease: compare South Sumatera.

http://vizhub.healthdata.org/gbd-compare/ 
Jategaonkar, N., \& Ponic, P. (2011). Unsafe \& unacceptable Housing: Health \& policy implications for women leaving violent relationships. Women's Health and Urban Life, 10(1), 32-58.

\section{http://hdl.handle.net/1807/27218}

Johns Hopkins University \& Medicine. (2020, July 8). COVID-19 Dashboard by the Center for Systems Science and Engineering (CSSE).

https://coronavirus.jhu.edu/map.html

Kanok-Nukulchai, W. (2020, April 18). Taking the fight to Covid-19 using simple mathematics. Bangkok Post.

https://www.bangkokpost.com/opinion/opinion/1902320/taking-the-fight-tocovid-19-using-simple-mathematics

Kawal Covid 19. (2020, July 9). Covid-19 in Indonesia (8 july 2020).

\section{https://web.facebook.com/KawalCOVID19/}

Kramarae, C., \& Spender, D. (Eds.). (1992). The knowledge explosion: Generation of feminist scholarship. New York: Teacher's college press

La, V. P., Pham, T. H., Ho, M. T., Nguyen, M. H., Nguyen, K. L. P., Vuong, T. T., ... Vuong, Q. H. (2020). Policy response, social media and science journalism for the sustainability of the public health system amid the COVID-19 outbreak: The vietnam lessons. Sustainability (Switzerland), 12(7), 1-27.

https://doi.org/10.3390/su12072931

Li, L., Yang, Z., Dang, Z., Meng, C., Huang, J., Meng, H., ... Shao, Y. (2020). Propagation analysis and prediction of the COVID-19. Infectious Disease Modelling, 5, 282-292. https://doi.org/10.1016/j.idm.2020.03.002

Li, R., Pei, S., Chen, B., Song, Y., Zhang, T., Yang, W., \& Shaman, J. (2020). Substantial undocumented infection facilitates the rapid dissemination of novel coronavirus (SARS-CoV2). Science (New York, N.Y.), 368(6490), 489-493.

https://doi.org/10.1126/science.abb3221

Lindsley, \& Mann. (2020, April 8). Indonesia was in denial over coronavirus. Now it may be facing a looming disaster. The Conversation.

https://theconversation.com/indonesia-was-in-denial-over-coronavirus-now-itmay-be-facing-a-looming-disaster-135436 
Yeni, Najmah, Sharyn Davies | ASEAN Journal of Community Engagement | Volume 4, Number 1, 2020

Lutz, C. S., Huynh, M. P., Schroeder, M., Anyatonwu, S., Dahlgren, F. S., Danyluk, G., ... Biggerstaff, M. (2019). Applying infectious disease forecasting to public health: A path forward using influenza forecasting examples. BMC Public Health, 19(1).

https://doi.org/10.1186/s12889-019-7966-8

Lykke, N. (2010). Feminist studies, a guide to intersectional theory, methodology and writing. New York: Routledge.

Lykes, M. B., \& Coquillon, E. (2007). Participatory and action research and feminisms: Towards transformative praxis In S. N. Hesse-Biber (Ed.), Handbook of feminist research: Theory and praxis (pp. 297-326). Thousand Oaks, CA: SAGE Publications.

Lykes, M. B., \& HershBerg, R. M. (2012). Participatory action research and feminism: Social inequalities and transformative praxis. In S. N. Hesse-Biber (Eds.), Handbook of feminist research: Theory and praxis. Thousand Oaks, CA: SAGE Publications.

Maguire, P. (1987). Doing participatory research: A feminist approach. Amherst, Massachusetts: University of Massachusetts.

https://www.researchgate.net/profile/Patricia_Maguire2/publication/44815297_D oing_Participatory_Research_A_Feminist_Approach/links/5712573108ae4ef745261 424/Doing-Participatory-Research-A-Feminist-Approach.pdf.

Massola, James (2020, July 6). Indonesia set to become third virus hotspot in Asia, expert warns. The Sydney Morning Herald.

https://www.smh.com.au/world/asia/indonesia-set-to-become-third-virus-hotspot-in-asia-expert-warns-20200706-

p559hi.html?fbclid=IwAR3n5eeM1p970xBsygbEZxKhDr7LfTmuAKXgCnp3toBC6xw HjyUKeYxW3ow

Medina, A. F. (2020, April 17). Thailand Grants Visa Extensions for Foreigners Impacted by COVID-19.

https://www.aseanbriefing.com/news/thailand-grants-visa-extensions-foreignersimpacted-covid-19/

Milne, G. J., Kelso, J. K., Kelly, H. A., Huband, S. T., \& McVernon, J. (2008). A small community model for the transmission of infectious diseases: Comparison of School closure as an intervention in individual-based models of an influenza pandemic. PLoS ONE, 3(12). 
Ministry of Health of RI. (2020a, April 12). Cara Mengajukan Permohonan Penetapan PSBB Untuk Solusi COVID-19 (How to Submit Application for PSBB Determination for COVID-19 Solutions).

https://covid19.kemkes.go.id/warta-infem/cara-mengajukan-permohonanpenetapan-psbb-untuk-solusi-covid-19/\#.Xr-1NmgzbIU

Ministry of Health of RI. (2020b, July 8). Covid 19-Update. https://infeksiemerging.kemkes.go.id/

Ministry of Health of RI. (2020c, May 20). DKI dan Jabar Sudah Terapkan PSBB, Pemerintah Minta Seluruh Masyarakat Disiplin Ikuti Aturan (DKI and West Java Have Implemented the PSBB, the Government Asks All Disciplinary Society to Follow the Rules).

https://www.kemkes.go.id/article/view/20041200004/dki-dan-jabar-sudahterapkan-psbb-pemerintah-minta-seluruh-masyarakat-disiplin-ikuti-aturan.html

Ministry of Health of RI. (2020d, May 14). PSBB Kota Palembang Disetujui Menkes (Palembang City PSBB Approved by Minister of Health).

https://www.kemkes.go.id/article/view/20051300002/psbb-kota-palembangdisetujui-menkes.html

Ministry of Health of RI. (2020e, May 11). Situasi Terkini Perkembangan Coronavirus (Covid-19) 11 Mei 2020 (Current Situation of Coronavirus Development (Covid-19) May 11, 2020).

https://covid19.kemkes.go.id/situasi-infeksi-emerging/info-corona-virus/situasiterkini-perkembangan-coronavirus-disease-covid-19-11-mei-2020/\#.Xr-p9WgzbIU

Ministry of Health of RI. (2020f, April 9). Situasi Terkini Perkembangan Coronavirus (COVID-19) 9 April 2020 (Current Situation of Coronavirus Development (COVID19) April 9, 2020).

https://infeksiemerging.kemkes.go.id/

Ministry of Health of RI. (2020g, April 1). Situasi Terkini Perkembangan Coronavirus Disease (COVID-19) 2 Maret 2020 (Current Situation Development of Coronavirus Disease (COVID-19) March 2, 2020). https://covid19.kemkes.go.id/situasi-infeksi-emerging/info-corona-virus/situasiterkini-perkembangan-coronavirus-disease-covid-19-2-maret-2020/\#.XsDjRGgzbIU 
Yeni, Najmah, Sharyn Davies | ASEAN Journal of Community Engagement | Volume 4, Number 1, 2020

Nguyen, T. H. D., \& Vu, D. C. (2020). Summary of the COVID-19 outbreak in Vietnam -

Lessons and suggestions. Travel Medicine and Infectious Disease, 101651. Advance online publication.

https://doi.org/10.1016/j.tmaid.2020.101651

Provincial Government of South Sumatra. (2020, July 16). Sumatera Selatan Tanggap Covid-19 (South Sumatera Response Covid-19).

http:/ /corona.sumselprov.go.id/index.php? module=home\&id=1

Pusdatin Ministry of Health of RI. (2019). Profil Kesehatan Indonesia tahun 2018 (Indonesia Health Profile in 2018). Jakarta.

Putra, A. Y. (2020, March 29). Update: 2 PDP Died in Positive South Sumatra Covid-19, Had Contact with 45 People. Kompas.

https://palembang.kompas.com/read/2020/03/29/14280511/update-2-pdpmeninggal-di-sumsel-positif-covid-19-sempat-kontak-dengan-45?page=all

Regmi, K., \& Naidoo, J. (2013). Understanding the processes of writing papers reflectively. Nurse researcher, 20(6), 33-39.

https://www.ncbi.nlm.nih.gov/

Reid, C., \& Frisby, W. (2008). Continuing the journey: Articulating dimensions of Feminist Participatory Action Research (FPAR). In P. Reason \& H. Bradbury (Eds.), Sage handbook of action research: Participative inquiry and practice (pp. 93-105). London, UK: SAGE.

Septianto, B. (2020, March 31). 3 Positive Cases of Corona Sumsel Have a History from Jakarta \& Bogor.

https://tirto.id/3-kasus-positif-corona-sumsel-miliki-riwayat-dari-jakarta-bogoreJXP

Smith, D., \& Moore, L. (2004). The SIR Model for Spread of Disease: The Differential Equation Model. Mathematical Association of America.

https://www.maa.org/press/periodicals/loci/joma/the-sir-model-for-spread-ofdisease-the-differential-equation-model

Soeriaatmadja, W. (2020, April 7). Indonesia ranks among world's worst in coronavirus testing rate. The Jakarta Post.

https://www.thejakartapost.com/news/2020/04/07/indonesia-ranks-amongworlds-worst-in-coronavirus-testing-rate.html 
Tamara Pilishvili, Razzaghi, H., Reed, N., Ritchey, M., \& Sauber-Schatz, E. (2020). Severe Outcomes Among Patients with Coronavirus Disease 2019 (COVID-19) - United States, February 12-March 16, 2020. In MMWR. Morbidity and mortality weekly report (Vol. 69).

https://doi.org/10.15585/mmwr.mm6912e2

The Institute for Disease Modeling. (2019). Understanding the Model.

https://doi.org/10.1002/9781119197171.ch9

T., Biju. (2020). Purakala Role of Kudumbashreein Covid-19 Containment in Kerala The Pandemic and the State of Kerala. UGC Care Journal, 31, 266-274.

https://www.researchgate.net/publication/342344924_Purakala_Role_of_Kudumba shreein_Covid-19_Containment_in_Kerala_The_Pandemic_and_the_State_of_Kerala

The Novel Coronavirus Pneumonia Response Epidemiology Team. (2020). The epidemiological characteristics of an outbreak of 2019 novel coronavirus diseases (COVID-19)—China, 2020. China CDC Weekly, 2(8), 113-122.

https://doi.org/10.46234/ccdcw2020.032

Turner, S. G., \& Maschi, T. M. (2015). Feminist and empowerment theory and social work practice. Journal of Social Work Practice, 29(2), 151-162.

https://doi.org/10.1080/02650533.2014.941282

Wallinga, J., \& Teunis, P. (2004). Different epidemic curves for severe acute respiratory syndrome reveal similar impacts of control measures. American Journal of Epidemiology, 160(6), 509-516.

https://doi.org/10.1093/aje/kwh255

World Health Organization. (2019). Non-pharmaceutical public health measures for mitigating the risk and impact of epidemic and pandemic influenza : annex: report of systematic literature reviews (No. WHO/WHE/IHM/GIP/2019.1). In No. 2019/1. https://apps.who.int/iris/bitstream/handle/10665/329439/WHO-WHE-IHM-GIP2019.1-eng.pdf?ua=1

World Health Organization. (2020, March 11). WHO Director-General's opening remarks at the media briefing on Covid-19-11 March 2020. World Health Organization.

https://www.who.int/dg/speeches/detail/who-director-general-s-openingremarks-at-the-media-briefing-on-covid-19---11-march-2020 
Worldometer. (2020, July 8). Covid-19 Coronavirus Pandemic (per 8 July 2020).

https://www.worldometers.info/coronavirus/\#countries

Yeni, Najmah, Davies, S.G. (2020, June 8). Modelling, Women's Empowerment and Covid-19 in South Sumatra-Indonesia. Presented in International Webinar ASEAN Journal of Community Engagement.

https://www.youtube.com/watch?v=Wwi12HrtQA8

Yeni, Hepiman, F., Mardiana, Najmah. (2020, June 8). PSBB versus New Normal Life. Laju Sumsel.

https://lajusumsel.com/677-baca-berita-psbb-versus-new-normal-life.html

Yoshihama, M., \& Carr, E. S. (2002). Community Participatin Reconsidered: Feminist Participatory Action Research with Hmong women. Journal of Community Practice $10(4), 18$.

https://doi.org/10.1300/J125v10n04_06 